Session 2315

\title{
ASCE's Raise the Bar Initiative: The Body of Knowledge for the Future
}

\author{
Stuart G. Walesh \\ Consultant and Author
}

\begin{abstract}
ASCE's Task Committee on Academic Prerequisites for Professional Practice (TCAP^3) was charged to develop, organize, and execute a detailed plan for the full implementation of ASCE Policy 465 (Academic Prerequisites for Licensure and Professional Practice). This paper presents the recommendations of TCAP^3's Body of Knowledge-Curricula Committee and, secondarily, describes the process used to arrive at those draft recommendations. The Committee's draft recommendations follow three themes: what should be taught and learned, how it should be taught and learned, and who should teach it.
\end{abstract}

\section{Introduction}

\section{Background}

ASCE created the Task Committee on Academic Prerequisites for Professional Practice (TCAP ${ }^{3}$ ) in October 2001 and charged it to "... develop, organize and execute a detailed plan for full realization of ASCE Policy Statement 465." The policy's essence is that ASCE supports the concept of a practice-oriented masters degree or equivalent as a requirement for licensure and the practice of civil engineering at the professional level.

As one step in carrying out that charge, $\mathrm{TCAP}^{3}$ formed the Body of Knowledge (BOK)-Curricula Committee in May 2002. The BOK-Curricula Committee was charged to:

Define, within the first six to nine months after committee formation (formed mid-May 2002), the body of knowledge (BOK) needed to enter the practice of civil engineering at the professional level (licensure) in the $21^{\text {st }}$ Century. Address the role of experience in the licensure preparation process. Design and/or identify Bachelors Plus Master's or 30 credits $(B+M / 30)$ programs plus experience that will implement the $B O K$ in the 
early part of the $21^{\text {st }}$ Century. Describe the role

of faculty and practitioners in imparting the BOK

by means of $B+M / 30$ programs. Seek input from

and support for the preceding from forward-

looking academics and practitioners.

The preceding charge includes "Bachelors Plus Master's or 30 Credits" and " $\mathrm{B}+\mathrm{M} / 30$." Each of these terms means the total post-secondary education that fulfills the BOK required for licensing and entry into the professional practice of civil engineering.

The BOK to be defined in support of ASCE Policy Statement 465 means the knowledge, skills and attitudes necessary to a licensed professional civil engineer. The BOK applies explicitly to those civil engineering educational tracks intended to prepare tomorrow's civil engineering student to become a practicing (licensed) professional engineer. The committee expects that the majority of BSCE graduates will want to follow the professional practice track.

\section{Purpose}

The purpose of this paper is to present the recommendations of the BOK-Curricula Committee and, secondarily, to describe the process used to arrive at those recommendations and, looking ahead, revise and refine them. Presented here are the Committee's BOK views and recommendations arranged by three themes; 1) what should be taught and learned, 2) how it should be taught to and learned by civil engineering students, and 3) who should teach it.

For additional details about the Committee's draft recommendations and the process by which they were developed, refer to the current version of the Committee's report titled Civil Engineering Body of Knowledge for the $21^{\text {st }}$ Century: Preparing the Civil Engineer for the Future. ${ }^{1}$ The current version of this evolving report is available on the ASCE website at http://www.asce.org/raisethebar.

\section{Caveats}

As indicated above, this paper is focused on the BOK and is not intended to address the need for raising the educational bar for civil engineers. That and related important topics are addressed in the 2001 report Engineering the Future of Civil Engineering ${ }^{2}$ also available on the ASCE website at http://www.asce.org/raisethebar.

The BOK discussed in this report was in an early draft when this paper was completed in March 2003. Accordingly, the BOK will have been revised or refined by the time this paper is presented in June 2003. Interested readers can obtain the current version of the BOK report at the ASCE website. 


\section{Process Used to Develop the Body of Knowledge}

\section{Form Diverse Core Committee}

Who should define the BOK? The Committee's charge includes seeking "input from and support for" defining the BOK from "forward-looking academics and practitioners." Accordingly, TCAP 3 started by forming a diverse BOK-Curricula Committee in May 2002. The Committee would not define the BOK; it would facilitate its definition. Committee composition (see appendix in this paper for members and, for more information, see appendix in the Committee's report ${ }^{2}$ ) will continue to evolve as needs and opportunities arise. Since its formation, the Committee conducted conference calls every two to three weeks, held three face-to-face meetings and continuously communicated with $\mathrm{TCAP}^{3}$ and with the other two constituent committees; the Accreditation Committee and the Licensure Committee.

\section{Look Forward}

The BOK-Curricula Committee tried to creatively contemplate the likely nature of infrastructure and environmental problems and opportunities decades ahead. The Committee avoided being overly bound by today's conditions. Instead, likely changes in infrastructure and environmental changes were considered. Possibilities include sea level rise, sharp decline in oil supplies, increased globalization (clients, employees, partners, projects), resurgence of nuclear power plants, mining of landfills, user fee-based transportation, privatization, increased multi-modal transportation, technology breakthroughs, a much larger senior population, and the need to more effectively interact with an increasingly knowledgeable and demanding public.

\section{Develop Evolving Work Plan}

The Committee prepared a work plan consisting of key tasks and selected milestones. The work plan (see appendix in the Committee's report ${ }^{2}$ ) has been and will continue to be updated and extended as the Committee's work proceeds. Included in the work plan are completed, in-process and planned tasks and deliverables.

\section{Interact With Corresponding Members}

Forming a group of corresponding members proved to be an effective feature of the Committee's approach. Corresponding members are mostly civil engineers from the public and private sectors and academia interested in the BOK aspects of ASCE Policy 465. They were willing to review draft materials, respond to questions, and otherwise provide ideas and information for consideration by the Committee. Corresponding members' approach enabled the Committee to greatly expand the breadth and depth of stakeholder input. Essentially all interaction with Corresponding Members has been via email. As of March, 2003, about 50 individuals had participated at least once (see appendix in the Committee's report ${ }^{2}$ ). Many thoughtful, detailed

"Proceedings of the 2003 American Society for Engineering Education Annual Conference \& Exposition Copyright (C) 2003, American Society for Engineering Education " 
comments have been received and have, in turn, been considered by the BOK-Curricula Committee and incorporated into the report.

\section{Present and Publish Papers and Articles and Participate in Conferences and Workshops}

Another element of the Committee's approach was participation in key conferences and workshops and writing BOK focused articles and papers for selected publications (see appendix in the Committee's report ${ }^{2}$ ). These activities provided another means of moving stakeholders from awareness to understanding and soliciting input and broadening support.

\section{Review Body of Knowledge Approach of Other Professions}

The Committee studied the BOK approaches of various, diverse professions as a means of learning from them and stimulating thinking. The Committee's white paper ${ }^{3}$ documents BOK ideas and information from within engineering and from other disciplines including accounting, architecture, construction, project management, and public administration. Highly varied approaches were discovered and, as a result, this research proved very useful.

\section{Communicate - Communicate - Communicate}

In addition to doing the preceding, many of which involved interaction with stakeholders, the BOK-Curricula Committee's approach includes, or will include, the following:

- Participation in ASCE's four annual zonal conferences in 2002 and 2003.

- Participation in most of ASCE's six annual Regional Department Head Councils.

- Use of the Department Heads Listserve on the ASCE website to solicit views on the draft BOK.

- Briefing and seeking support of ASCE's Educational Activities Committee (1/02, 10/02).

- Searching for existing practice-oriented BS-Masters programs that may be consistent with the draft BOK and interacting with the faculty at those institutions.

- Exploring distance education providers, including traditional universities, agencies, and private sector entities, and their offerings for possible compatibility with the BOK.

- Briefing the ASCE Board of Direction on the status of the BOK effort $(11 / 02,5 / 03)$.

- Briefing the ASEE Dean's Council (planned for 2003). 


\section{Concluding Thoughts About the Process Being Used to Develop the BOK}

The BOK-Curricula Committee, with the support of $\mathrm{TCAP}^{3}$ and working in parallel with the Licensure and Accreditation Committees, has endeavored to adopt a communicative, inclusive, proactive, creative and thorough approach to carrying out its charge. Questions, suggestions, criticisms and other forms of input are invited and most welcome. Anyone interested in actively participating in the Committee's work is urged to contact the author.

\section{Body of Knowledge - What Should be Taught and Learned}

\section{An Outcomes Approach}

The Committee chose outcomes as the starting point for its outcome deliberations, taking into account study of BOK models used by other professions and entities ${ }^{3}$. By outcomes, the Committee means knowledge, skills, and attitudes a civil engineer must have for practicing civil engineering at the professional level. The Committee chose ABET's 11 outcomes as the starting point. The draft ASCE commentary on program criteria ${ }^{4}$ was also reviewed.

The understanding was that the Committee would begin with and be informed by the ABET outcomes, but would not be constrained by them in breadth and/or depth. The Committee soon discovered that carrying out its charge required a broader and deeper statement of outcomes than that provided by the ABET outcomes, even when existing program criteria for civil and similarly named engineering programs were considered.

The breadth necessary for defining the Civil Engineering BOK for the $21^{\text {st }}$ Century resulted in specifying 18 individual outcomes. The required depth was achieved by accompanying each outcome with a commentary the purpose of which was to elaborate on and illustrate each outcome's intent. The outcome-commentary format provides what the committee views as a desirable deliverable for stakeholders; a list of succinct outcomes, each linked, for the purpose of providing more depth, to an explanatory commentary.

Outcomes are viewed as being applicable over a long period of time (e.g., decades). In contrast, some illustrative topics mentioned in commentaries will be ephemeral, requiring modification in response to technological advances and other changes.

\section{The Outcomes}

Using outcomes and commentaries, the Committee recommends that the Civil Engineering BOK for the $21^{\text {st }}$ Century be as presented here. Parenthetic notes at the end of some outcomes link them to ABET's 11 outcomes, that is, the outcome is identical to the indicated ABET outcome. The outcomes collectively prescribe the necessary depth and breadth of knowledge, skills and attitudes required of an individual aspiring to enter the practice of civil engineering at the professional level (licensure) in the $2{ }^{\text {st }}$ Century. Relative to to day's basic programs, the outcomes prescribe both

"Proceedings of the 2003 American Society for Engineering Education Annual Conference \& Exposition Copyright (C) 2003, American Society for Engineering Education " 
additional breadth and more technical depth. The $21^{\text {st }}$ Century civil engineer must demonstrate:

1. an ability to apply knowledge of mathematics, science and engineering. (ABET a)

Commentary: The common technical core of mathematics, science and engineering underlying the professional role of the civil engineer as the master integrator includes most of the following: mathematics through differential equations, probability and statistics, calculus-based physics, biology, chemistry, ecology, geology/geomorphology, engineering economics, mechanics, material properties, systems, geo-spatial representation, and information technology. A technical core of knowledge and breadth of coverage in mathematics, science and civil engineering topics are stressed in this outcome.

2. an ability to design and conduct experiments, as well as analyze and interpret data. (ABET b)

Commentary: Civil engineers frequently design and conduct field and laboratory studies, gather data and then analyze and interpret the results. Be able to do this in at least one of the major recognized civil engineering areas. Examples are traffic, geotechnical, and water quality investigations.

3. an ability to design a system, component, or process to meet desired needs. (ABET c)

Commentary: Important design or design procurement elements are bidding versus quality-based engineer selection; estimating engineering costs; interaction between planning, design and construction; ownerengineer relationships; life-cycle assessment; sustainability; and design methodology and process, including problem definition, scope, analysis, risk assessment, creativity, synthesizing alternatives, iteration, codes, safety, security and constructability; multiple objectives and perspectives. Understanding large-scale systems is important, including the need to integrate information, organizations, people, processes, and technology. Design experiences should be integrated throughout the professional component of the curriculum.

4. an ability to function on multi-disciplinary teams. (ABET d)

Commentary: Lead a design or other team as well as participate as a member of a team. Demonstrate an understanding of team formation and evolution, team dynamics, collaboration among diverse disciplines, problem solving, and time management.

"Proceedings of the 2003 American Society for Engineering Education Annual Conference \& Exposition Copyright $\odot$ 2003, American Society for Engineering Education " 
5. an ability to identify, formulate and solve engineering problems. (ABET e)

Commentary: Assess situations in order to identify engineering problems, formulate alternatives and recommend feasible solutions.

6. an understanding of professional and ethical responsibility. (ABET f)

Commentary: Demonstrate an understanding of and a commitment to practice according to the seven Fundamental Canons of Ethics and the associated Guidelines to Practice Under the Fundamental Canons of Ethics.

7. an ability to communicate effectively.(ABET g)

Commentary: Effective communication includes listening, observing, speaking and writing and requires understanding of the fundamentals of interacting effectively with technical and nontechnical or lay individuals and audiences in a variety of settings. Be versatile with mathematics, graphics, the worldwide web and other communication tools.

8. the broad education necessary to understand the impact of engineering solutions in a global and societal context.(ABET h)

Commentary: Appreciate, from historical and contemporary perspectives, culture, human and organizational behavior, aesthetics and ecology and their impacts on society. Include history and heritage of the civil engineering profession.

9. a recognition of the need for, and an ability to engage in life-long learning. (ABET i)

Commentary: Life-long learning mechanisms available for personal and professional development include additional formal education, continuing education, professional practice experience, community service, coaching, mentoring, and other learning and growth activities.

- Personal and professional development can include developing understanding of and competence in goal setting, personal time management, communication, delegation, personality types, networking, leadership, the socio-political process, and effecting change. 
- Professional development can, in addition to the preceding, include career management, increasing discipline knowledge, understanding business fundamentals, contributing to the profession, considering selfemployment, achieving licensure and specialty certification, and additional graduate studies.

10. a knowledge of contemporary issues. (ABET $\mathrm{j}$ )

Commentary: Appreciate the relationship of engineering to critical contemporary issues such as globalization of engineering practice; the growing diversity of society; and the technical, environmental, societal, political, legal, aesthetic, economic, and financial implications of engineering projects.

11. an ability to use the techniques, skills, and modern engineering tools necessary for engineering practice. (ABET k)

Commentary: This includes the role and use of appropriate information technology, contemporary analysis and design methods, and applicable design codes and standards as practical problem-solving tools to complement knowledge of fundamental concepts. Also included is the ability to select the appropriate tools for solving different types and levels of problems.

12. an ability to apply knowledge in a specialized area related to civil engineering.

Commentary: For a professional civil engineer, experience plus graduate, specialized technical coursework (or the equivalent) is expected for this outcome. Examples of specialized technical areas that might be selected are structural engineering, construction engineering and management, public works management, transportation engineering and water resources management. Specializations in non-traditional or emerging fields such as ecological engineering are encouraged. Coursework in traditional Master of Business Administration (MBA) or Juris Doctorate programs would usually not fulfill this outcome, unless elective courses were used to emphasize a specialized technical area related to civil engineering. For example, an MBA program might include a sequence of specialized, technical courses emphasizing project management to fulfill this outcome. While both undergraduate and graduate education program structures include elements of breadth and depth, it is expected that the majority of graduate coursework would be devoted to a specialized, technical area. 
13. understanding of the elements of project management.

Commentary: Project management essentials include project manager responsibilities, defining and meeting requirements, risk assessment, stakeholder identification and involvement, contract negotiation, scope and deliverables, and budget and schedule preparation and monitoring.

14. understanding of business fundamentals as applied to private, government, and nonprofit sectors.

Commentary: Important topics include legal forms of ownership, organizational structures and design, income statements, balance sheets, decision (engineering) economics, finance, marketing and sales, billable time, overhead, and profit.

15. understanding of public policy and administration fundamentals.

Commentary: Essential elements include the political process, public policy, laws and regulations, funding mechanisms, public education and involvement, government-business interaction, and the public service responsibility of professionals.

16. understanding of the elements of asset management.

Commentary: Asset management seeks effective and efficient long-term ownership of capital facilities via systematic acquisition, operation, maintenance, preservation, replacement, and disposition. Goals include optimizing life-cycle performance, minimizing life-cycle costs, and achieving maximum stakeholder benefit. Tools and techniques include design innovations, new construction technologies, materials improvements, geo-mapping, database management, value assessment, performance models, web-based communication, and cost accounting. Introducing asset management recognizes that civil engineers, during their careers, are likely to be involved with some aspect of capital facilities management.

17. understanding of the elements of construction.

Commentary: Important construction elements are owner-engineercontractor relationships; project delivery systems (e.g., design-bid-build, design-build); estimating construction costs; bidding by contractors; labor and labor and management issues; and construction processes, methods, systems, equipment, planning, scheduling, safety, cost analysis and cost 
control.

18. understanding the role of the leader and leadership principles.

Commentary: Leading, which differs from and complements managing, requires broad motivation, direction, and communication knowledge and skills. Attitudes generally accepted as being conducive to leadership include positiveness, persistence, curiosity, creativity, empathy, confidence, judgment, entrepreneurship, integration, and a service orientation. Desirable behaviors of leaders, which can be taught and learned, include earning trust, trusting others, formulating and articulating vision, honesty and integrity, rational thinking, openness, consistency, commitment to organizational values, and discretion with sensitive information.

\section{Comparison of BOK and ABET Outcomes and Some Implications}

Recall that the ABET outcomes were used by the committee as a starting point in developing an outcome-based definition of the civil engineering BOK for the $21^{\text {st }}$ Century and are included as the first 11 outcomes. This prompts Figure 1, which presents the 18 outcomes recommended by the committee for civil engineers as an expansion of the current 11 ABET outcomes.

Figure 1. The 18 outcomes in the recommended BOK consist of the ABET's 11 outcomes plus one depth outcome and six breadth outcomes.

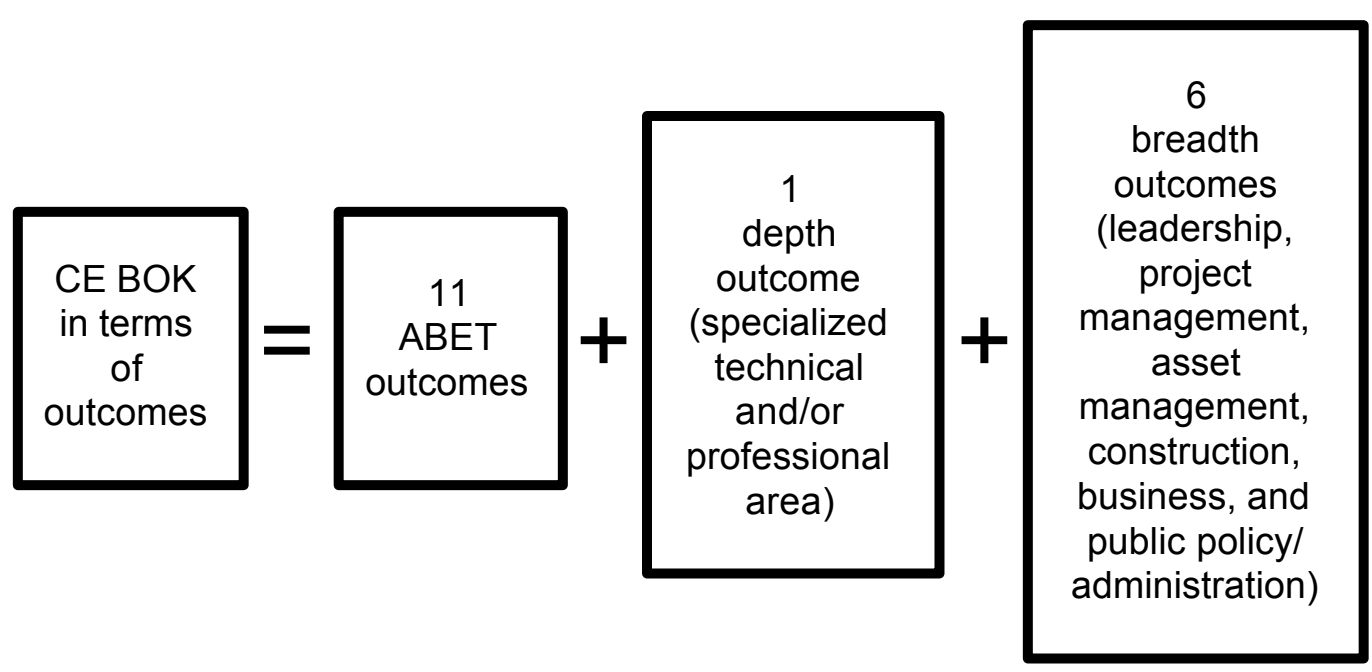

Note: Each outcome is supported by a commentary that elaborates on and illustrates the outcome's intent for civil engineering practice. Commentaries are an essential part of the outcomes. Refer to the text for commentaries. 
The preceding leads to the following observations:

- All 11 ABET outcomes are included in the BOK outcomes where they appear as the first 11 outcomes.

- One of the seven new outcomes (Outcome 12) reflects the specialization embodied in ASCE Policy Statement 465. That specialization can be in a technical or professional area. The manner in which this outcome is achieved would vary widely among institutions and among future civil engineers.

- A high degree of flexibility in meeting Outcome 12 is expected at the institutional level because the specialty or specialties selected would reflect each institution's culture, traditions and strengths. For example, one civil engineering department might select a technical specialization, such as structural engineering, while another might select a professional practice topic such as project management.

- A high degree of flexibility in meeting Outcome 12 is also expected at the individual level. That flexibility could occur in two ways. First, in the choice between technical specialization or a broader professional practice area. Second, in the choice of the teaching/learning mode. With respect to the second kind of flexibility, the future civil engineer would expect to find a wide variety of master's degree programs which, when coupled with his or her bachelor's degree, would help provide the BOK. Or the individual could design a program of approximately 30 semester credits of acceptable graduate level or upper level undergraduate courses to supplement his or her bachelor's degree and help provide the BOK.

- The remaining new outcomes (Outcomes 13-18) reflect the additional professional and practice knowledge, skills, and attitudes embodied in ASCE Policy Statement 465. More specifically, these new outcomes address leadership, project management, asset management, construction, business and public policy and administration.

As faculty leaders in civil engineering departments begin to think about expanding their programs, or articulating their undergraduate programs with graduate programs at other institutions, to meet the expanded civil engineering BOK for the $21^{\text {st }}$ Century, they are urged to build on those program elements that meet the current ABET criteria. Why? Because the civil engineering BOK of the future includes the current ABET outcomes as the foundation upon which the future or our profession will be constructed.

However, in preparing curricula for the future, consideration should be given to the whole, that is, both the undergraduate and graduate experience. Some desirable program elements that are now in the undergraduate portion (e.g., a second structural design course) might be more appropriate for the graduate position. Moving to $\mathrm{B}+\mathrm{M} / 30$ as the formal education means to fulfill the $\mathrm{BOK}$ 
provides an opportunity to broaden the undergraduate teaching and learning experience. This is essentially impossible, within the present baccalaureate degree model, without sacrificing technical content. A holistic approach provides an opportunity to take a fresh look at undergraduate programs.

\section{Body of Knowledge - $\underline{\text { How }}$ Should it be Taught and Learned?}

\section{Importance of Formal Education Plus Experience}

Having defined what constitutes the BOK, the Committee considered how it should be taught and learned. The three teaching/learning modes are:

- Undergraduate study typically leading to a Bachelor of Science in Civil Engineering (BSCE);

- Practice-oriented graduate study or equivalent; and

- Post-BS engineering experience prior to licensure.

The Committee concluded that the BSCE will be the primary means of initiating the teaching and learning of most outcomes. Furthermore, based on its breadth and depth of knowledge, skills, and attitudes, that BSCE could provide an attractive and appropriate liberal education for the $21^{\text {st }}$ Century. On earning the broader BSCE, a graduate would have many varied attractive options. Examples are:

- Working in the civil engineering public or private sector in a support role not requiring a license.

- Gaining experience creditable toward licensure with the intent of eventually earning a practice-oriented masters degree or " 30 " as a full or part-time student and doing so in a traditional manner, via distance learning or in some combination of the two methods of access.

- Studying and entering another field such as business, law, or education.

Both upper level undergraduate and post-baccalaureate education and structured post-BS experience (E) are essential to achieving the BOK. That is, neither experience nor post-BS education alone will prepare the holder of a BS degree to enter the practice of civil engineering at the professional level. The abbreviation $\mathrm{B}+\mathrm{M} / 30$ \& E expresses the means to fulfill the BOK.

While structured post-BS experience is essential, experience interspersed within formal education is valuable. Increased university - employer collaboration can assure that essentially all future civil 
engineering practitioners have the opportunity to enhance their learning and increase their awareness of the vitality of the profession by participation in additional experienced-based learning during formal education. Examples are: cooperative education, internships, summer paraprofessional employment, and part-time or full-time para-professional employment prior to earning a BS degree.

\section{Curricula Design Projects}

The Committee is searching for existing undergraduate-graduate programs that approximate, in terms of outcomes, the BOK defined in this report. Furthermore, the Committee has begun working with selected civil engineering departments that want to be leaders in designing BS and master's degree tracks that will provide the prescribed BOK.

Colorado State University (CSU) was the first institution to join the effort. Beginning with a November 2002 on-campus workshop, the CSU Department of Civil Engineering is simultaneously conducting a critical review of the BOK and designing an undergraduate-graduate program consistent with the BOK. A similar workshop was conducted at Iowa State University (ISU) in January 2003 and ISU has joined the effort. As of March 2003, a March workshop was scheduled at Cast Western Reserve University and a May workshop was scheduled at California State University - Los Angeles. The BOK-Curricula Committee seeks collaboration with other public and private, primarily undergraduate and research-oriented institutions in similar curricular design projects.

\section{Distance Learning and the Non-Degree Path}

The Committee concludes that distance learning, especially the web-based category, will increasingly provide an effective means for developing the knowledge, skills, and attitudes included in the BOK. Finally, the Committee expects that the majority of civil engineers seeking licensing will follow a path that leads from an ABET accredited baccalaureate through an accredited practice-oriented engineering master's degree. Validating attainment of the BOK through an ABET baccalaureate and 30 hours of upper level undergraduate work plus graduate work will be more complex. Various validation approaches, such as mentoring and participation by $\mathrm{ABET}$, universities and other entities, are being examined.

\section{Body of Knowledge - Who Should Teach It?}

From the onset of discussion on this topic, the following four faculty-related success factors became evident to the BOK-Curricula Committee.

- Educators and practitioners: The who for the civil engineering BOK should include educators, that is, full-time civil engineering and other faculty, and also many practitioners. Participation by the latter means in-depth involvement with full-time faculty and students; this involves much more than guest lecturing.

"Proceedings of the 2003 American Society for Engineering Education Annual Conference \& Exposition Copyright $\odot$ 2003, American Society for Engineering Education " 
"Proceedings of the 2003 American Society for Engineering Education Annual Conference \& Exposition Copyright (C) 2003, American Society for Engineering Education "

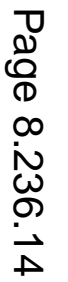


- Expertise: For simple adequacy in the classroom, all teachers should acquire and maintain a high-level of expertise in the subject that they are teaching. For civil engineering, this suggests that practical experience be obtained and that most faculty hold engineering licenses.

- Teaching effectiveness: Student learning is sub-optimal, or may not occur, when faculty and practitioners do not effectively engage students in the learning process. Those who teach should have proper preparation to teach.

- Role modeling: Every civil engineer who is in contact with students serves as a role model for the profession. Therefore, all teachers and practitioners should be aware that students are viewing them as such.

These are explicit success factors for those who will teach the $21^{\text {st }}$ Century civil engineers. They reflect the need and the opportunity to raise the bar in all three dimensions of the civil engineering BOK; the what, the how, and the who.

\section{Issues and Concerns Relevant to Academia}

Having presented the Committee's BOK ideas and considering the attendees of this conference, thoughts naturally flow to how the BOK is or will be received across academia. Faced with a markedly changed BOK, as cast in terms of what, how, and who, many issues and concerns are likely to be understandably raised by civil engineering faculty and department heads/chairs, and by engineering deans and other university administrators. Some possible issues and concerns are listed here to demonstrate that the Committee is aware of them and to solicit more. The Committee is confident that civil engineering departments choosing to lead curricula reform will find positive and creative ways to address the listed and other issues and concerns.

1. Need for more evidence, preferably quantitative, that civil engineering educational reform is necessary.

2. Added institutional costs (e.g., faculty, staff, equipment, space, accreditation) to accommodate students in traditional and new Masters programs. What if we incur costs and "no one comes?"

3. Added costs to students. Will students and their families be willing and able to invest more in their education and will employers assist with the cost of $M / 30$ ?

4. Reduced civil engineering enrollment. Added time and monetary cost, as viewed by counselors, prospective students, and their parents, may drive students away from civil engineering. This could be further aggravated by other engineering disciplines appearing "easier."

"Proceedings of the 2003 American Society for Engineering Education Annual Conference \& Exposition Copyright (C) 2003, American Society for Engineering Education " 
5. Fear that this is another false start. That is, those educators who lead will not have the civil engineering profession's on-going support. Some will say "they" tried this before (e.g., Cornell University) and it didn't work. As a result, time and energy will be wasted.

6. Civil engineering will be doing something different than electrical engineering, mechanical engineering, chemical engineering, etc. Let's wait until "everyone is on board."

7. Our institution would be doing something different. Let's wait until other institutions pave the way. Why put ourselves at a competitive disadvantage?

8. Major additional work would be required. We are already asked to do too much.

9. Reluctance of individual faculty or departments to give up autonomy even though successful implementation of a deeper and broader BOK would seem to require more collaboration within engineering schools and colleges as well as across the campus.

10. Exclusively undergraduate CE programs may lose legitimacy. They would no longer provide the entire required formal education.

11. Civil engineering programs that offer Masters degrees may be pressured to lower entrance standards. Shouldn't we admit most of our BSCE graduates to at least one of our Masters programs?

12. Interference with research programs, especially revenue generated and prestige gained. Why? Because some faculty may want to devote more effort to improving the curriculum.

13. Lack of incentives for a sufficient number of civil engineering and other faculty to focus on curricula reform. ${ }^{1}$

14. Reluctance to embrace more non-technical topics in existing courses or consider adding non-technical courses. "Non-technical" means management, leadership, business, communication and humanities and social sciences. Civil engineering faculty tend to lack experience and/or interest in these areas and be uncomfortable with them. Furthermore, although non-technical resources are typically available on university campuses, interdepartmental and/or inter-college working relationships are often lacking.

15. Desire to "load up" on technical topics and courses. Some civil engineering faculty will support a lengthened formal academic program and then strongly advocate "filling" the extra credit slots with only or mostly technical content. This conflicts with the intent of Policy Statement 465.

16. Fear of change. Shared by many.

"Proceedings of the 2003 American Society for Engineering Education Annual Conference \& Exposition Copyright $\odot$ 2003, American Society for Engineering Education " 


\section{The Next Steps}

The Committee's work will continue in the form of implementation-oriented actions and additions. The Committee will refine its BOK findings and recommendations by continuous interaction with stakeholders, primarily within ASCE. Critical continued and/or new tasks include:

- Expansion of the Corresponding Members group and on-going email interaction with them.

- Continued active participation in key conferences and workshops and presentation and publication of papers.

- Interaction with ASCE student chapters and their faculty and practitioner advisors, industry leaders, the CE Department Heads Council, deans, CE Chairs/Heads, and the ASCE Educational Activities Committee (EdAC).

- Interaction with the practice community including individual practitioners plus their public and private employers.

- Documentation of existing supportive undergraduate-graduate tracks and distance learning programs and focused partnerships with $\mathrm{CE}$ departments in designing new undergraduate-graduate tracks.

- Identification of funding sources primarily for curriculum development projects.

- Assistance to $\mathrm{TCAP}^{3}$ 's Accreditation and Licensure Committees.

\section{Closing Thoughts}

Working on the what, how, and who of the BOK needed to enter the practice of civil engineering at the professional level (licensure) in the $21^{\text {st }}$ Century is challenging. The effort is worthwhile, however, because gradual implementation of mechanisms for teaching and learning the BOK will markedly strengthen the CE profession. Increasingly, newly licensed civil engineers will possess a broader and deeper suite of knowledge, skills, and attitudes that will enable them to more effectively:

- Hold paramount public safety, health, and welfare;

- Participate in the formulation of - as well as the implementation of - programs and projects related to their expertise;

- Guard the natural environment and create a sustainable built environment;

"Proceedings of the 2003 American Society for Engineering Education Annual Conference \& Exposition Copyright $\odot$ 2003, American Society for Engineering Education " 
- Conceive, plan, design, and manage large civil infrastructure systems including transportation, water, wastewater, structures, land use, energy, and security;

- Integrate an increasingly diverse workforce;

- Lead global technology development and transfer; and

- Grow personally and professionally throughout their careers.

\section{Acknowledgements}

The author acknowledges the contributions of other members of the BOK-Curricula Committee and assistance from Corresponding Members and members of the Accreditation and Licensure Committees and TCAP ${ }^{3}$. TCAP ${ }^{3}$ and its constituent committees, including the BOK-Curricula Committee, were markedly influenced by and respectfully and appreciatively built on the visionary and diligent work of others. Many individuals and groups, working creatively and persistently over decades, developed influential ideas and information. Engineering education and practice literature document these efforts. The BOK-Curricula Committee gratefully acknowledges assistance received from earlier and contemporary contributions of others.

\section{Bibliography}

1. ASCE Body of Knowledge - Curricula Committee of the Task Committee on Academic Prerequisites for Professional Practice. 2003. Civil Engineering Body of Knowledge for the 21 ${ }^{\text {st }}$ Century: Preparing the Civil Engineer for the Future. February 27. (This is an evolving report and the current version is available on the ASCE website at http://www.asce.org.)

2. ASCE Task Committee on the First Professional Degree. 2001. Engineering the Future of Civil Engineering, October 9. (Available on the ASCE website at http://www.asce.org.)

3. ASCE Body of Knowledge - Curricula Committee of the Task Committee on Academic Prerequisites for Professional Practice. 2003. Moving Toward a Civil Engineering Body of Knowledge of the $21^{\text {st }}$ Century: Background. January.

4. ASCE Committee on Curricula and Accreditation and ASCE Department Heads Council. 2002. "Commentary - ASCE - Program Criteria for "Civil" and Similarly Named Engineering Programs." Draft 7. May.

5. For thoughtful, in-depth discussion of "desirable characteristics of an objective, unambiguous, and fair reward system for engineering faculty at research universities with an emphasis on the role of teaching, see Roesset, J. M. and J. T. P. Yao. 2002. "A Preliminary White Paper on Faculty Reward Systems in Research Universities." Department of Civil Engineering. Texas A\&M University. College. December.

"Proceedings of the 2003 American Society for Engineering Education Annual Conference \& Exposition Copyright (C) 2003, American Society for Engineering Education " 
"Proceedings of the 2003 American Society for Engineering Education Annual Conference \& Exposition Copyright (C) 2003, American Society for Engineering Education "

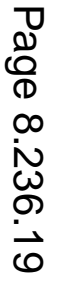




\title{
Appendix: Members of the Body of Knowledge-Curricula Committee
}

\author{
Abbie Dement, EI \\ Michael J. Chajes, PhD, PE \\ Gerald Galloway, Jr., PhD, PE \\ Chris T. Hendrickson, $\mathrm{PhD}$ (Vice-Chair) \\ Ralph J. Hodek, PhD, PE \\ Thomas A. Lenox, $\mathrm{PhD}$ \\ Jim O'Brien, PE \\ Dale W. Sall, PE, LS \\ John S. Shearer, PE, DEE \\ Tomas Siller, $\mathrm{PhD}$ \\ Stuart G. Walesh, PhD, PE (Chair) \\ Marlee A. Walton, PE
}

\section{Biography}

Independent consultant STUART G. WALESH, PhD, PE (stuwalesh@aol.com) provides leadership, management and engineering services to private and public organizations drawing on experience as project manager, department head, discipline manager, marketer, professor and engineering dean. He authored many papers and several books including Engineering Your Future, ASCE Press, 2000 and Flying Solo, Hannah Publishing, 2000.

/P\&PASEE03Paper

$3 / 24 / 03$

"Proceedings of the 2003 American Society for Engineering Education Annual Conference \& Exposition

Copyright (C) 2003, American Society for Engineering Education " 